\title{
Rehabilitation of Reinforced Concrete Deep Beams Using Carbon Fiber Reinforced Polymers (CFRP)
}

\author{
Shereen K. H. Hassan ${ }^{1}$, Mu `tasim S. Abdel-Jaber ${ }^{1} \&$ Maha Alqam $^{1}$ \\ ${ }^{1}$ Department of Civil Engineering, The University of Jordan, Amman, Jordan \\ Correspondence: Mu'tasim Abdel-Jaber, Department of Civil Eng ineering, The University of Jordan, Amman, \\ 11942, Jordan.E-mail: m.abduljaber@ju.edu.jo
}

Received: July 9, 2018

Accepted: July 19, 2018

Online Published: July 28, 2018

doi:10.5539/mas.v12n8p 179

URL: https://doi.org/10.5539/mas.v12n8p179

The research is financed by the Deanship of Academic Research at The University of Jordan.

\begin{abstract}
Reinforced concrete structures that incorporates deep beams are generally susceptible to deterioration due to weathering effects and sulphur attacks, under-design in the detailing of concrete cover and/or re inforcement, and construction errors. In lieu of demolishing and replacing these structures, rehabilitation and strengthening using carbon fiber composites becomes a cost-effective viable alternative. Recent advances in research and innovation have introduced concrete repair and strengthening systems that are primarily based on fiber reinforced polymer composites. These systems have offered engineers the opportunity to provide additional stability to the structural elements in question and to restore the damaged portions back to their original load carrying capacity.

This paper investigates the effect of Carbon Fiber Reinforced Polymer (CFRP) composites in enhancing the flexural performance of damaged reinforced concrete deep beams. Two types of CFRP composites and epoxy were used in the experimental investigation carried out and as described by this paper: 1) high strength carbon fiber reinforced polymer (CFRP) plates, commercially known as MBrace Laminate, that are bonded using an epoxy resin specifically suited for the installation and used to strength en existing structural members; and, 2) MBrace Fiber 230/4900, a 100\% solids, low viscosity epoxy material that is used to encapsulate MBrace carbon, glass, and aramid fiber fabrics so that when it cures, it provides a high performance FRP sheet.

Test samples were divided into four groups: A control group, and three rehabilitated test groups with CRFP fibers, where the main variable among them was the percent length of CRFP used along the bottom beam extreme surface between supports (i.e, for two of the groups reinforced with MBrace laminates), and the use of MBrace Fiber 230/4500 CRFP sheets on the $4^{\text {th }}$ beam along its vertical sides as well as the bottom extreme face between supports. All beams had similar cross-sectional dimensions and reinforcement, and were designed to fail in flexure rather than shear.

The results show that CFRP composites, both laminated and sheet type, have increased the load carrying capacity in comparison to the control specimen, where observations were recorded pertaining to the delayed formation of vertical flexural cracks at the section of maximum mo ment, and diagonal shear cracks at beam ends. The increase in the load carrying capacity varied among the three rehabilitated test group beams, with the $4^{\text {th }}$ group showing the highest ultimate load carrying capacity when compared to the control specimen.
\end{abstract}

Keywor ds: deep beams, CFRP, flexural strengthening, laminates, sheets

\section{Introduction}

Reinforced Concrete Deep Beams (RCDBs) are considered one of the most important structural elements in civil engineering practice and are widely used in different types of structures, such as tall buildings, offshore structures, foundations, bridges, transfer girders, and shear walls (A1-Sarraf et al., 2011; Attarde and Barbat, 2015; Attarde and Parbat, 2016; Kong, 2006; and Suresh and Kulkarni, 2016).

Deep beams are popular for the structural horizontal elements of long spans where the number of intermediate supports are limited by architectural or navigational reasons. Because of the low span to depth ratio of deep beams when compared to normal flexural elements, Hooke's Law which states that plain sections remain plain 
before and after bending no longer holds, and their analysis, design, thereby further complicating design and detailing. As a result, the significance of shear deformations in deep beams become more pronounced when compared to their shallow counterparts (Al-Sarraf et al., 2011; Attarde and Parbat, 2016; and Nawy, 2009).

For deep beams built outdoors, deterioration and loss of member carrying capacity can result from exposure to detrimental environmental conditions during their service life, under-design, incorrect construction practices, or even the desire to increase the load carrying capacity of a perfectly sound structural system (David et al., 1998). Cracking and spalling of the concrete cover is considered one of the most primary reasons for the deterioration phenomenon, as cracking and spalling will cause loss in carrying capacity as well as allow for corrosion and exposure to adverse environmental conditions long term (Ahmad, et al., 2012; and Kim and Yun, 2011).

Several techniques have been reported in the technical literature, including the injection of polymer modified mortar (PMM) into the cracks in normal beams (Ahmad et al, 2012), or, in the case of deep beams, the use of external carbon fiber reinforced polymer (CFRP) (Obaidat et al, 2011), as well as the use of unbonded post-tensioned carbon fiber reinforced polymer rods (Burningham et al, 2015).

For deep reinforced concrete beams when compared to regular shallow beams both hav ing the same shear and flexural re inforcements, shear failure is most likely to occur in deep beams rather than in regular beams. Thus, retrofitting of deep beams with shear deficiencies using externally bonded reinforcement such as carbon fiber reinforced polymer (CFRP) becomes an excellent solution. The advantages of using CRFP are numerous and include their relatively high tensile strength, lightweight, excellent corrosive resistance, high durability, ease of installation, and above all, the significant increase in the flexural and shear load carrying capacity of the structural member once the CRFP fibers are bonded to the exterior surface of the deep beam members (Ahmadi, 2013; Ali et al., 2013; Benjeddou et al., 2007; David et al., 1998).

This investigation deals with the use of CRFP fibers in full or partially along the extreme bottom concrete surface of the deep beam, as well as investigating the effect of using $U$ type jacketing along the beam sides and extreme beam surface. The investigation compares the load vs. deflection relationship of the CRFP strengthened beams relative to the control beam and analyses the development of crack location and width along the members, with special emphasis on the type of failure at ultimate nominal resistance (i.e., pure flexure, pure shear, or flexural-shear).

\section{Experimental Program}

Experimental tests were conducted on a series of ten simply supported RCDBs under one concentrated load to investigate the use of externally bonded CFRP to restore and repair damaged RCDBs. Construction of all the test specimens was conducted according to ACI318M-14, ASTM C293-02 and ACI 440.2R-08 specifications.

Tests were carried out for:

1 Undamaged reinforced concrete deep beams subjected to one concentrated load (control specimens).

2 Damaged re inforced concrete deep beams to $60 \%$ of average ultimate load of control beams; then rehabilitated with CFRP and subjected to one concentrated load.

The test specimens were divided into four groups: a control test group and three rehabilitated test groups with CFRP fibers. Table 1 summarizes the details of each test specimen.

Table 1. Details of the test specimens

\begin{tabular}{|c|c|c|c|c|c|c|}
\hline Group & Description & Specimen & Rehabilita & Details & & \\
\hline Name & & Designation & $\begin{array}{l}\text { CFRP } \\
\text { material }\end{array}$ & Rehabilitation Scheme & $\begin{array}{l}\text { Fibers } \\
\text { Orientation }\end{array}$ & Place of Test \\
\hline \multirow[t]{2}{*}{$\begin{array}{l}\text { Control } \\
\text { Beam }\end{array}$} & \multirow[t]{2}{*}{ Two Control Beams } & CB1 & ------- & ------- & --------- & $\begin{array}{l}\text { JU* / Concrete } \\
\text { Lab }\end{array}$ \\
\hline & & $\mathrm{CB} 2$ & ----- & ------ & ------- & $\begin{array}{l}\text { JUST } * * / \\
\text { Structural Lab }\end{array}$ \\
\hline Group I & $\begin{array}{l}\text { Three } \\
\text { Rehabilitated Beams }\end{array}$ & $\begin{array}{l}\mathrm{RB} 1-1 \\
\mathrm{RB} 1-3 \\
\mathrm{RB} 1-2\end{array}$ & Laminate & $\begin{array}{l}\text { Two strips of laminate covering the } \\
\text { full width of the beam between the } \\
\text { supports }\end{array}$ & $0^{0}$ & $\begin{array}{l}\text { JUST } * * / \\
\text { Structural Lab } \\
\text { JU* / Concrete } \\
\text { Lab }\end{array}$ \\
\hline Group II & $\begin{array}{l}\text { Three } \\
\text { Rehabilitated Beams }\end{array}$ & $\begin{array}{l}\text { RB2-1 } \\
\text { RB2-3 }\end{array}$ & Laminate & $\begin{array}{l}\text { Two strips of laminate covering the } \\
\text { full width of the beam with a total }\end{array}$ & $0^{0}$ & $\begin{array}{l}\text { JUST } * * / \\
\text { Structural Lab }\end{array}$ \\
\hline
\end{tabular}




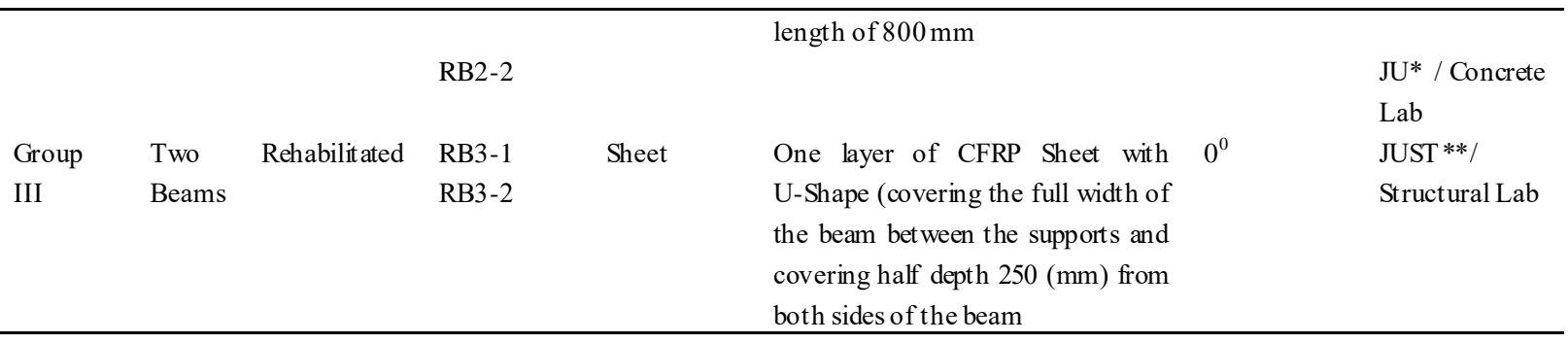

*JU: The University of Jordan.

**JUST: Jordan University of Science and Technology.

\subsection{Test Specimens}

All tested RCDBs had cross-sectional dimensions of $200 \mathrm{~mm}$ width, $500 \mathrm{~mm}$ depth and $1800 \mathrm{~mm}$ length. The ten test specimens were designed to fail in flexu re rather than shear. Design of test specimens was according to ACI318M-14, ASTM C293-02 and ACI 440.2R-08 specifications. The type of reinforcement used in this test for all test specimens was high yield strength deformed bars of grade 60 (ksi) wh ich have minimum yield strength of 420 (MPa). Two type of deformed bar reinforcement were used in RCDBs; and they are $2 \Phi 14$ as minimum longitudinal top and bottom reinforcement; $25 \Phi 12$ closed stirrups and three layers of $2 \Phi 12$ as horizontal reinforcement. Dimensions and reinforcement details of test specimens are illustrated in Figure 1.

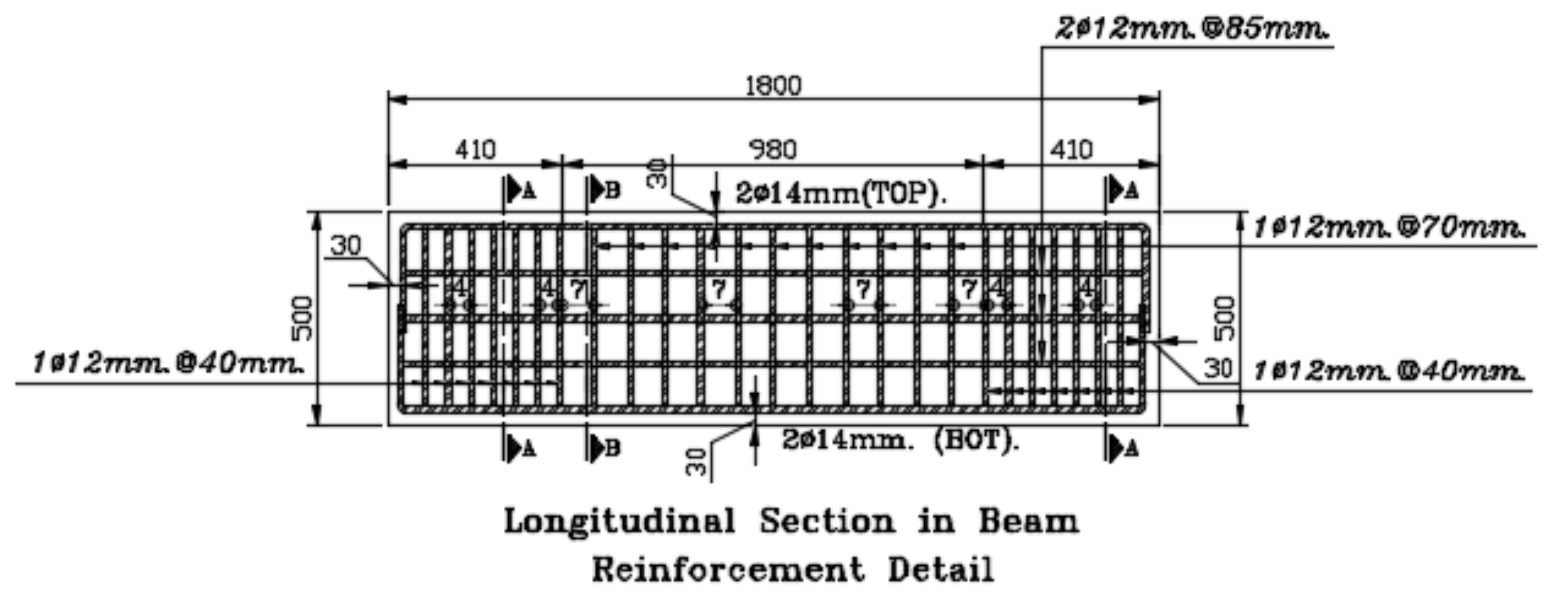

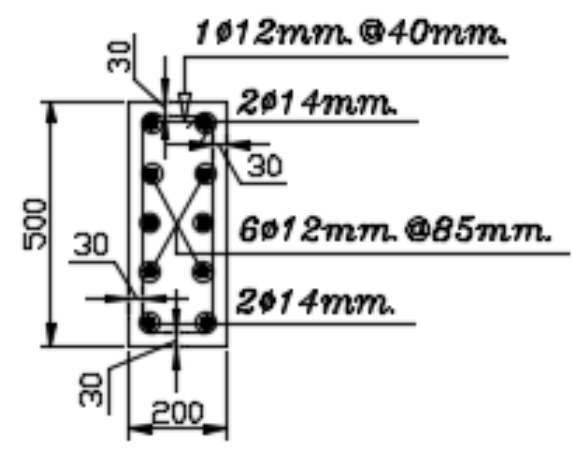

Section (A-A)

Reinforcement Detail
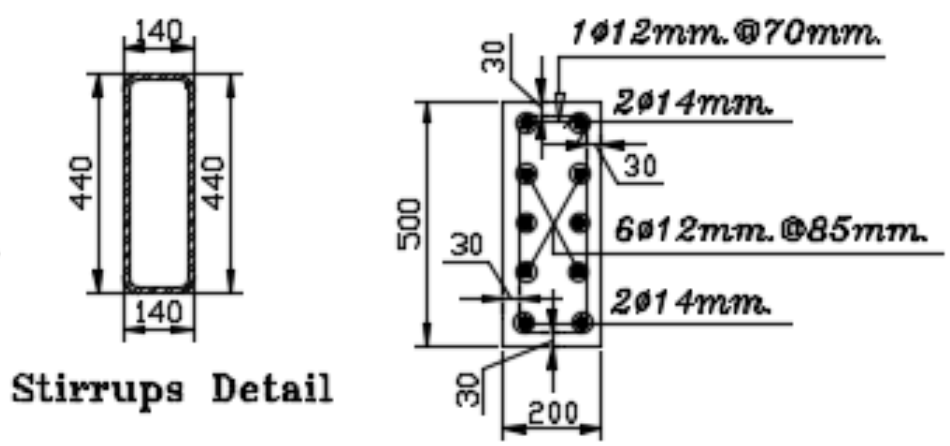

Section (B-B)

Reinforcement Detail 


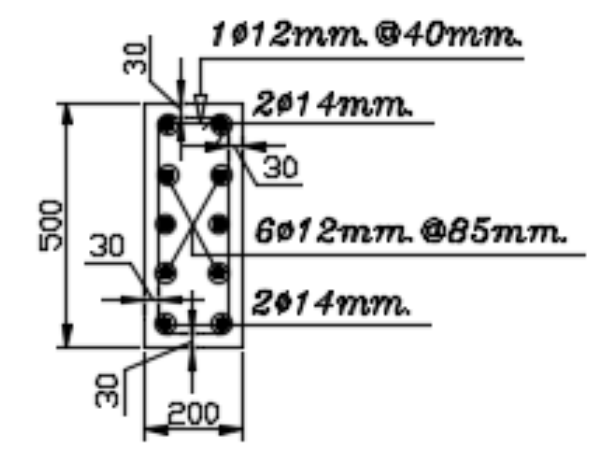

Section (A-A)

Reinforcement Detail
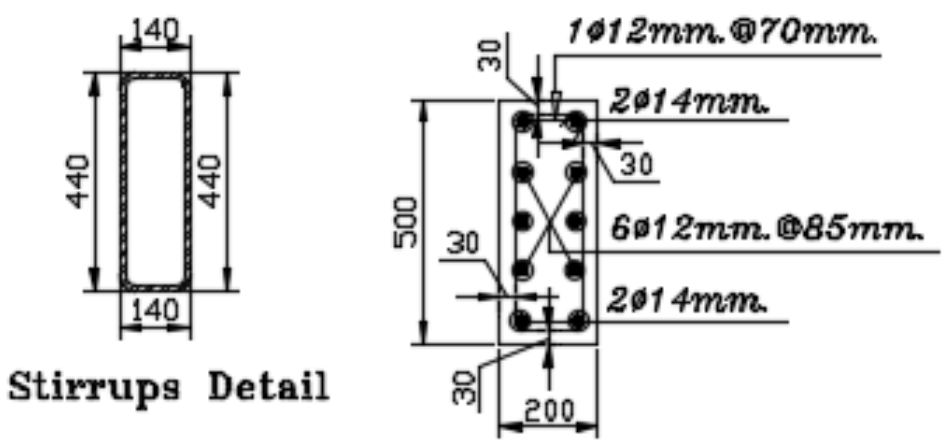

\section{Section (B-B) \\ Reinforcement Detail}

Figure 1. Dimension and Reinforcement Details of Test Specimens

(All dimensions are in millimeters)

A ready mix concrete with an average value of cubic compressive strength 23.8 (MPa) was used for casting the RCDBs.

\subsection{CFRP Material and Rehabilitated Schemes}

During the investigation of this study, two types of CFRP and epoxy resin were used during the rehabilitation procedure and they were MBrace Laminate with MasterBrace ADH 2200 and MBrace Fiber 230/4900 with MasterBrace SAT 4500. Typical properties of the CFRP materials are illustrated in Table 2.

Table 2. Typical Properties of MBrace Laminate and MBrace Fiber

\begin{tabular}{ccc}
\hline Property & \multicolumn{2}{c}{ CFRP Material } \\
\cline { 2 - 3 } & MBrace Laminate & MBrace Fiber 230/4900 \\
\cline { 2 - 3 } Fiber Tensile Strength (MPa) & $>2.80$ & 4.9 \\
Fiber Design Thickness (mm) & 1.4 & 0.166 \\
Width of Fiber (mm) & 100 & 500 \\
\hline
\end{tabular}

As a first step in rehabilitation procedure, all RCDBs were cleaned from any improper things like dust, laitance and loose material with a suitable sandpaper followed by washing them with water and then drying to ensure that RCDBs were clean. The next step was painting the required surface of RCDBs with a thin layer of epoxy resin approximately $3 \mathrm{~mm}$ followed by attaching CFRP laminate or sheet according to the adopted scheme and finally painting another layer of epoxy resin onto the CFRP with adequate pressure by a suitable hammer to remove any entrapped air bubbles. The RCDBs were cured for a minimum period in winter of fourteen days at room temperature. Epoxy is considered an essential part during rehabilitation procedure; for this reason two types of epoxy were used for CFRP material to avoid any debonding between the concrete surface and CFRP. Both types of epoxy resin in this study consisted of two components; a resin and a hardener. Both types of CFRP materials and Epoxy resin are shown in Figure 2.

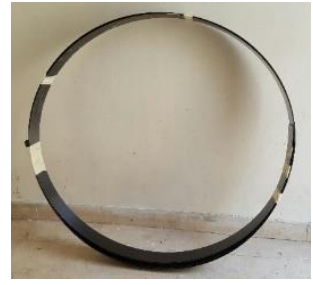

Mbrace Laminate

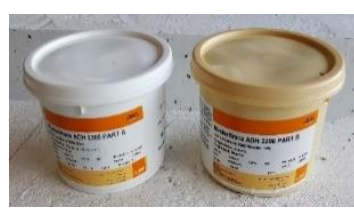

MasterBrace ADH 2200

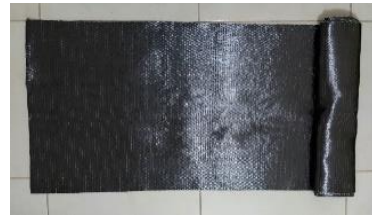

MBrace Fiber 230/4900

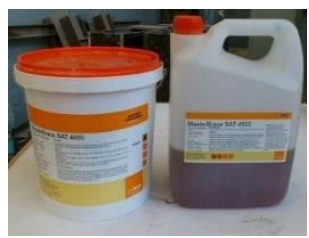

MasterBrace SAT 4500

Figure 2. Types of CFRP Materials and Epoxy Resin 
The second and third test groups were enhanced with two strips of MBrace laminate (each strip $100 \mathrm{~mm}$ wide) bonded externally to the bottom side of the beam and covering the full width of the beam between the supports in the $2^{\text {nd }}$ test group and with a length equal to $400 \mathrm{~mm}$ from left and right side of centre line of the beam in the $3^{\text {rd }}$ test group (i.e. with total length equal to $800 \mathrm{~mm}$ ), while $4^{\text {th }}$ test group was enhanced with a U-shape of MBrace Fiber 230/4900 covering full width of the beam between the supports and covering half of the depth from both sides of the beam. Schemes of CFRP materials of three rehabilitated test groups are illustrated in the Figure 3.
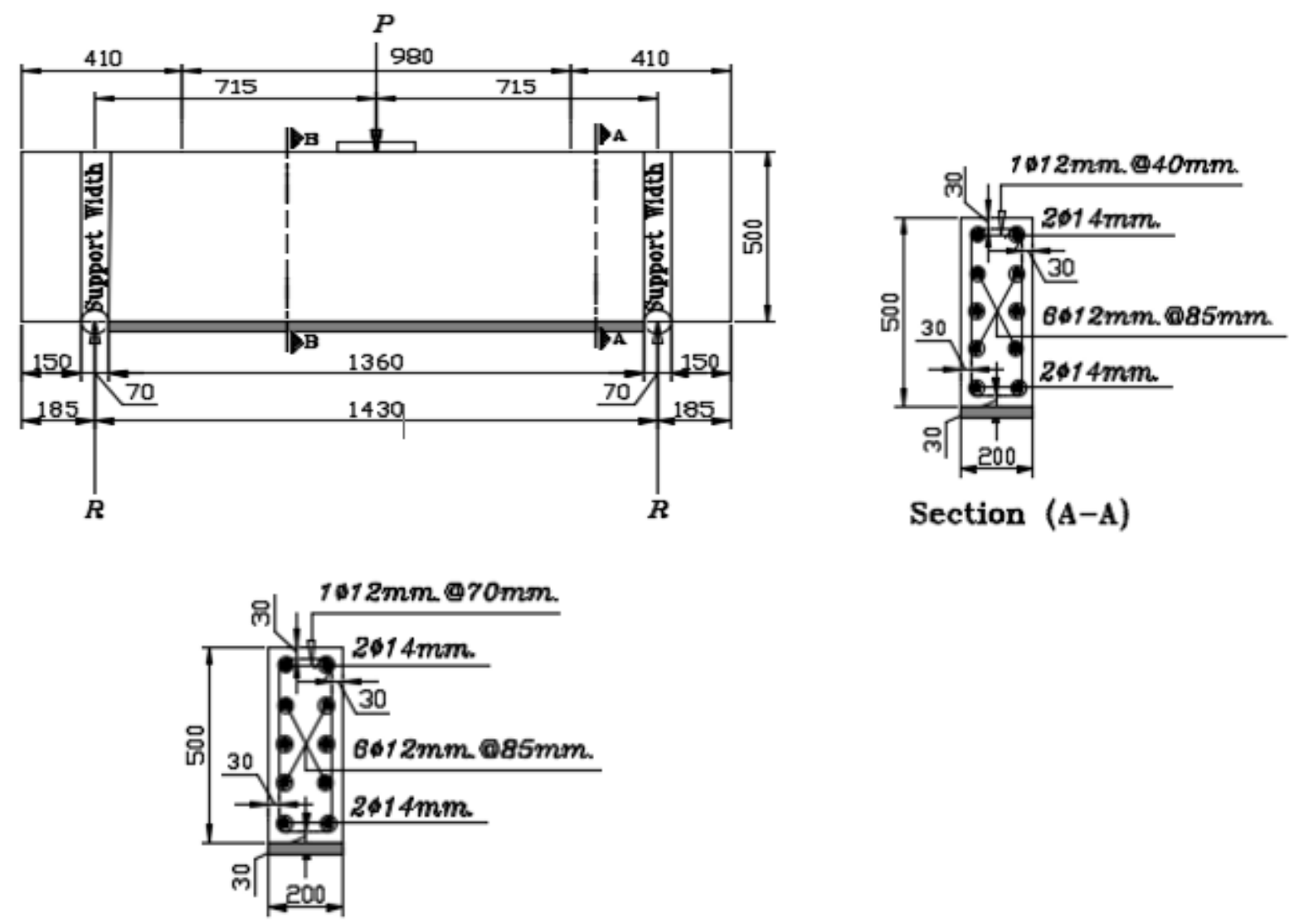

\section{Section (B-B)}

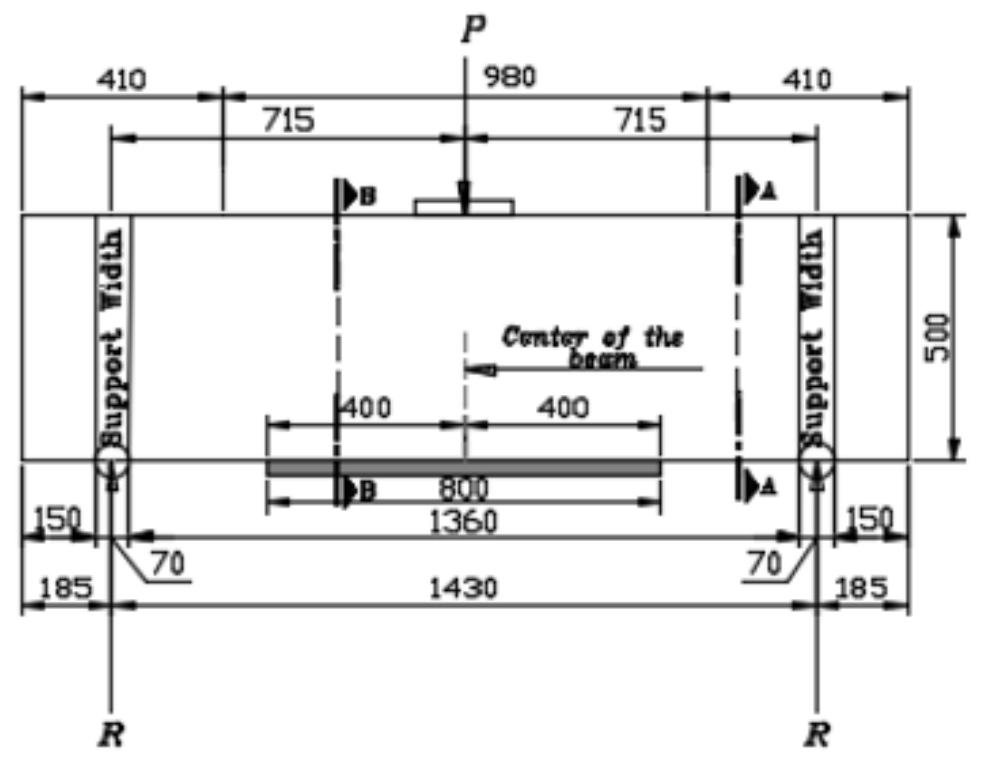

(RB1-1, RB1-2 and RB1-3)

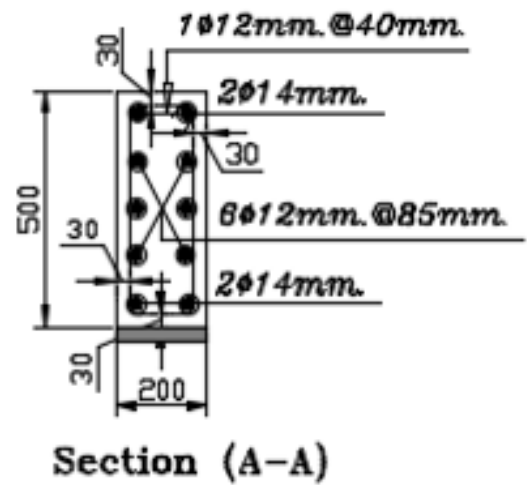




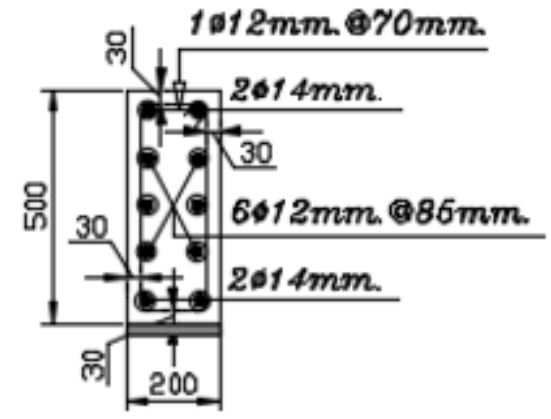

\section{Section (B-B)}

(RB2-1, RB2-2 and RB2-3)
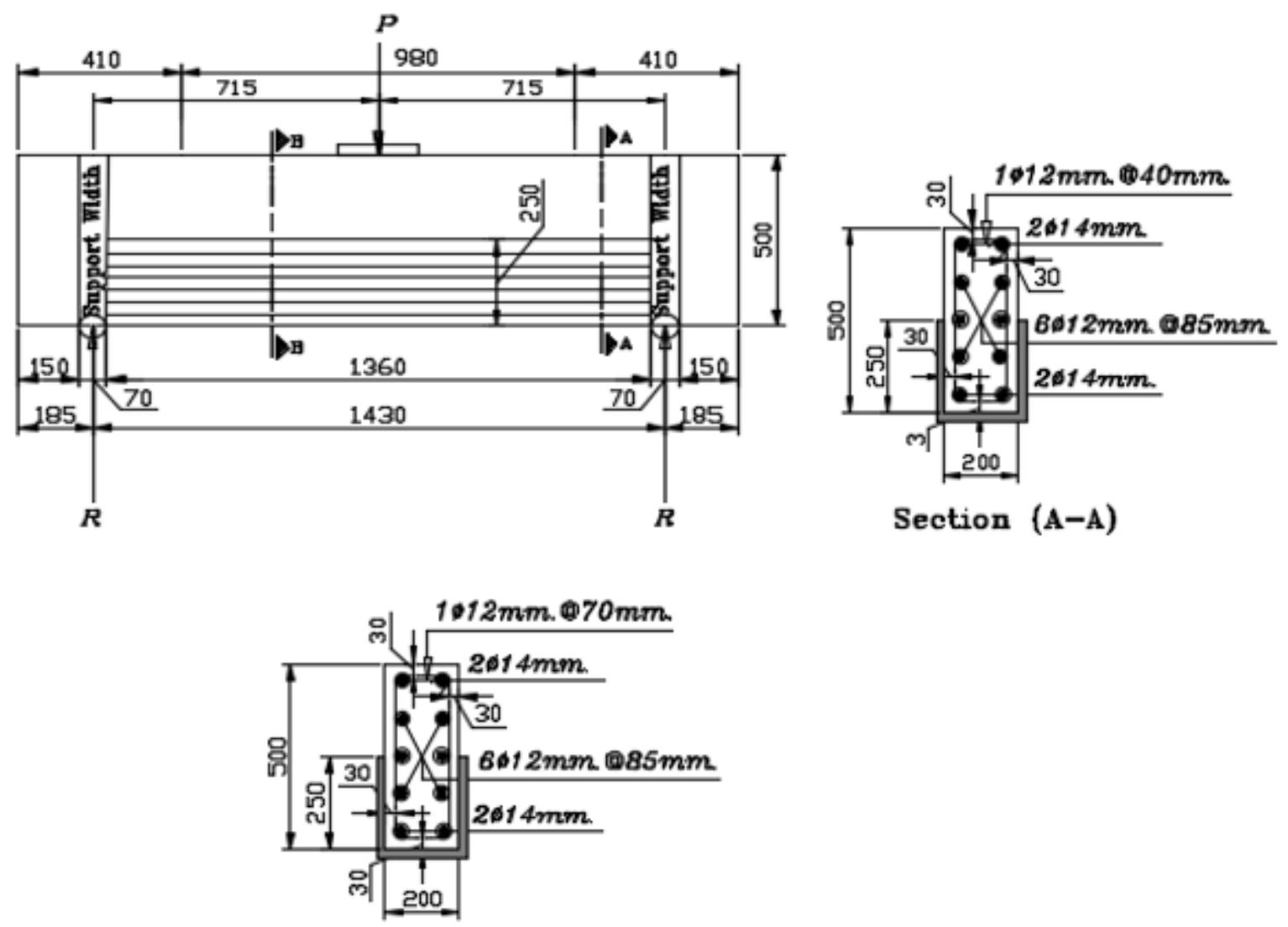

Section (B-B)

(RB3-1 and RB3-2)

Figure 3. Schemes of CFRP Materials for Rehabilitated Test Groups

(All dimensions are in millimeters)

\subsection{Experimental Setup and Procedure}

Some of the specimens were tested in the concrete lab at the University of Jordan (JU) and due to a technical problem with the testing machine; the remaining specimens were tested in the structurallab at the Jordan University of Science and Technology (JUST). All RCDBs were tested under one concentrated loads at both universities. Different loading rates were used during the test at both universities and they are as follows:
A. $2.5 \mathrm{kN} / \mathrm{second}$ at University of Jordan in concrete lab.
B. $2.0 \mathrm{kN} / \mathrm{second}$ at University of Jordan in concrete lab.
C. $0.5 \mathrm{kN} / \mathrm{second}$ at Jordan University of Science and Technology in structural lab. 
Figure 4 illustrates test setup of specimens at both Universities.
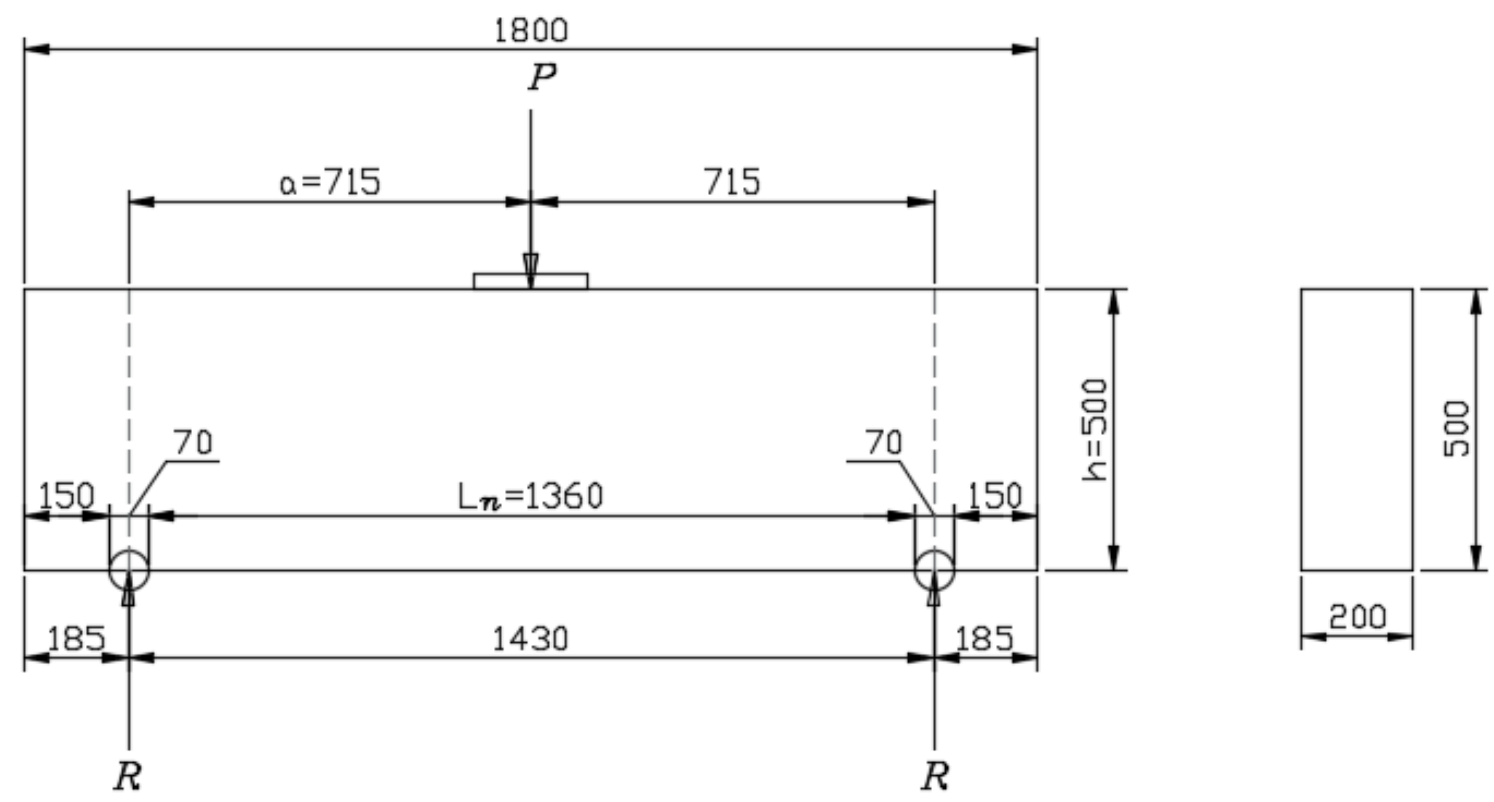

Figure 4. Test Setup (all dimensions are in millimeters)

During testing procedure, vertical mid-span deflection as well as formation of cracks with their propagation were recorded at each loading stage.

\section{Results and Discussion}

In the following sections, results of the control beam group will be introduced first and then the results of the rehabilitated beam groups will be compared with the control beam group in a table format. Also plots of load versus vertical mid-span deflection and failure mode at ultimate load capacity will be presented.

\subsection{Results of the Control Beam Group}

\subsubsection{Ultimate Strength}

Results of the control beam group with respect to the formation of the first vertical hair line flexural and shear cracks, the increased width of vertical flexu ral cracks, the ultimate load capacity and the failu re mode at ultimate load capacity in addition to a comparison between their results are presented. Initially, hair line vertical flexural cracks were observed at the mid-span of the beams and by increasing the load, diagonal shear cracks in both shear spans and from both supports were started to appear, and when reach ing high load values, vertical flexural cracks increased in width. Table 3 summarizes test results of control beam group.

Table 3. Test Results of Control Beam Group

\begin{tabular}{|c|c|c|c|c|c|}
\hline \multirow{3}{*}{ Comparison Issue } & \multicolumn{5}{|c|}{ Specimen Designation } \\
\hline & \multicolumn{2}{|l|}{ CB1 } & \multicolumn{2}{|l|}{$\mathrm{CB} 2$} & \multirow{2}{*}{$\begin{array}{l}\begin{array}{l}\text { Difference between } \\
\text { Control Beams }\end{array} \\
\% \text { of Difference }\end{array}$} \\
\hline & $\begin{array}{l}\text { Load } \\
(\mathrm{kN})\end{array}$ & $\begin{array}{l}\% \text { of Ultimate } \\
\text { Load }\end{array}$ & Load $(\mathrm{kN})$ & $\begin{array}{l}\% \text { of Ultimate } \\
\text { Load }\end{array}$ & \\
\hline $\begin{array}{l}\text { First Vertical Hair Line } \\
\text { Flexural Crack }\end{array}$ & 200 & $37.3 \%$ & 95.3 & $19.5 \%$ & $17.8 \%$ \\
\hline $\begin{array}{l}\text { Diagonal Shear Crack in } \\
\text { Right Shear Span }\end{array}$ & 238 & $44.4 \%$ & 205.6 & $42.1 \%$ & $2.3 \%$ \\
\hline Diagonal Shear Crack in & 238 & $44.4 \%$ & 226.1 & $46.3 \%$ & $1.9 \%$ \\
\hline
\end{tabular}




\begin{tabular}{|c|c|c|c|c|c|}
\hline \multicolumn{6}{|l|}{ Left Shear Span } \\
\hline $\begin{array}{l}\text { Diagonal Shear Crack at } \\
\text { Right Support }\end{array}$ & 271 & $50.6 \%$ & 232.2 & $47.5 \%$ & $3.1 \%$ \\
\hline $\begin{array}{l}\text { Diagonal Shear Crack at } \\
\text { Left Support }\end{array}$ & 296 & $55.2 \%$ & 208.8 & $42.8 \%$ & $12.4 \%$ \\
\hline $\begin{array}{l}\text { Widen Width of Vertical } \\
\text { Flexural Cracks }\end{array}$ & 400 & $74.6 \%$ & 371 & $76 \%$ & $1.4 \%$ \\
\hline Ultimate Load Capacity & 536 & --------- & 488.4 & --------- & ------- \\
\hline $\begin{array}{l}\text { Average Ultimate Load } \\
\text { Capacity }\end{array}$ & \multicolumn{4}{|c|}{512.2} & ------. \\
\hline $\begin{array}{l}\text { Failure Mode at Ultimate } \\
\text { Load Capacity }\end{array}$ & \multicolumn{2}{|c|}{ Pure Flexural Failure } & \multicolumn{2}{|c|}{ Pure Flexural Failure } & ------- \\
\hline
\end{tabular}

3.1.2 Load versus Vertical Mid-Span Deflection

\section{Load vs Deflection}

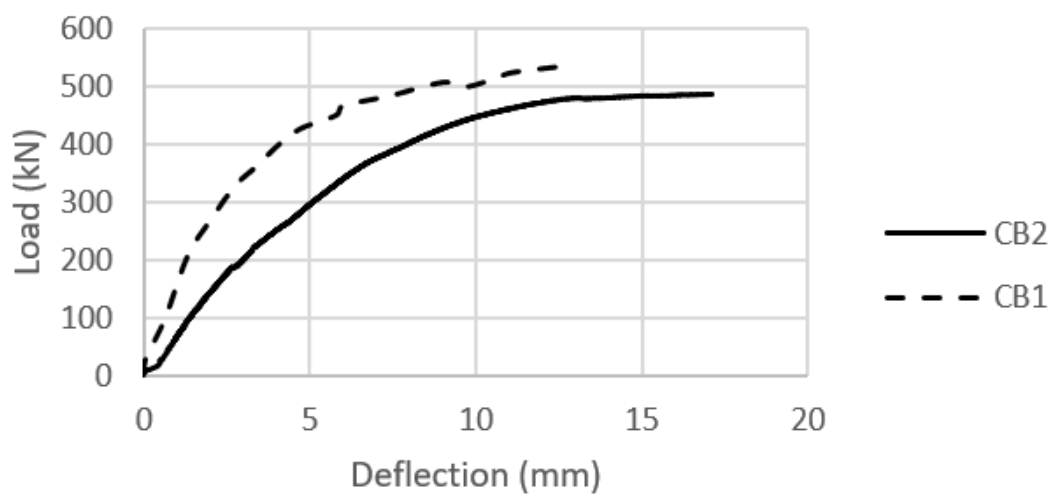

Figure 5. Comparison of Load versus Vertical Mid-Span Deflection between CB1 and CB2

According to Table 3 and Figure 5, there are some differences in the results between the two control beams, and this can be attributed to the difference in the testing machines with different load rates and the vibration process during casting might not have been the same between the two control beams since the vibration was manually undertaken due to the small spacing between stirrups.

\subsubsection{Failure Modes}

Before reaching the ultimate capacity, obvious widening in vertical flexural cracks at the mid-span of the beam with a rapid increase in the deflection values were observed; the latter indicates that yielding of the longitudinal reinforcement started at this stage. Both control beams failed in a ductile manner as expected. Figure 6 illustrates pure flexural failure of both control beams.

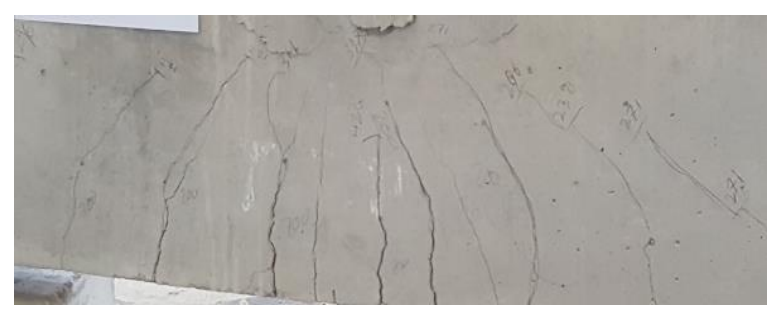

CB1

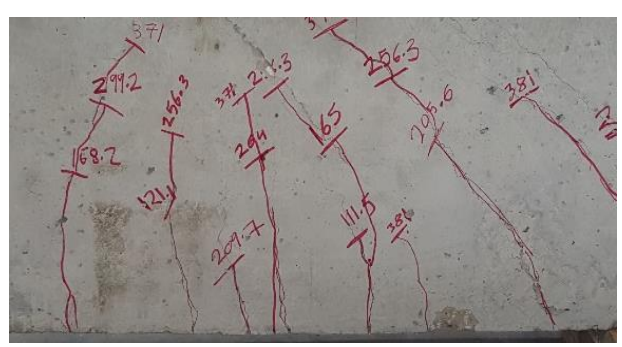

CB2

Figure 6. Pure Flexural Failure of $\mathrm{CB} 1$ and $\mathrm{CB} 2$ at Ultimate Load Capacity 


\subsection{Results of the Rehabilitated Beam Groups}

In this section, the results of the rehabilitated beam groups are presented in a comparison with the control beams group. From the eight rehabilitated beams, two beams (RB1-2 and RB2-2) are excluded from the results due to a sudden tilt in the hydraulic jack and the specimen. Figure 7 illustrates tilting of the two excluded specimens.
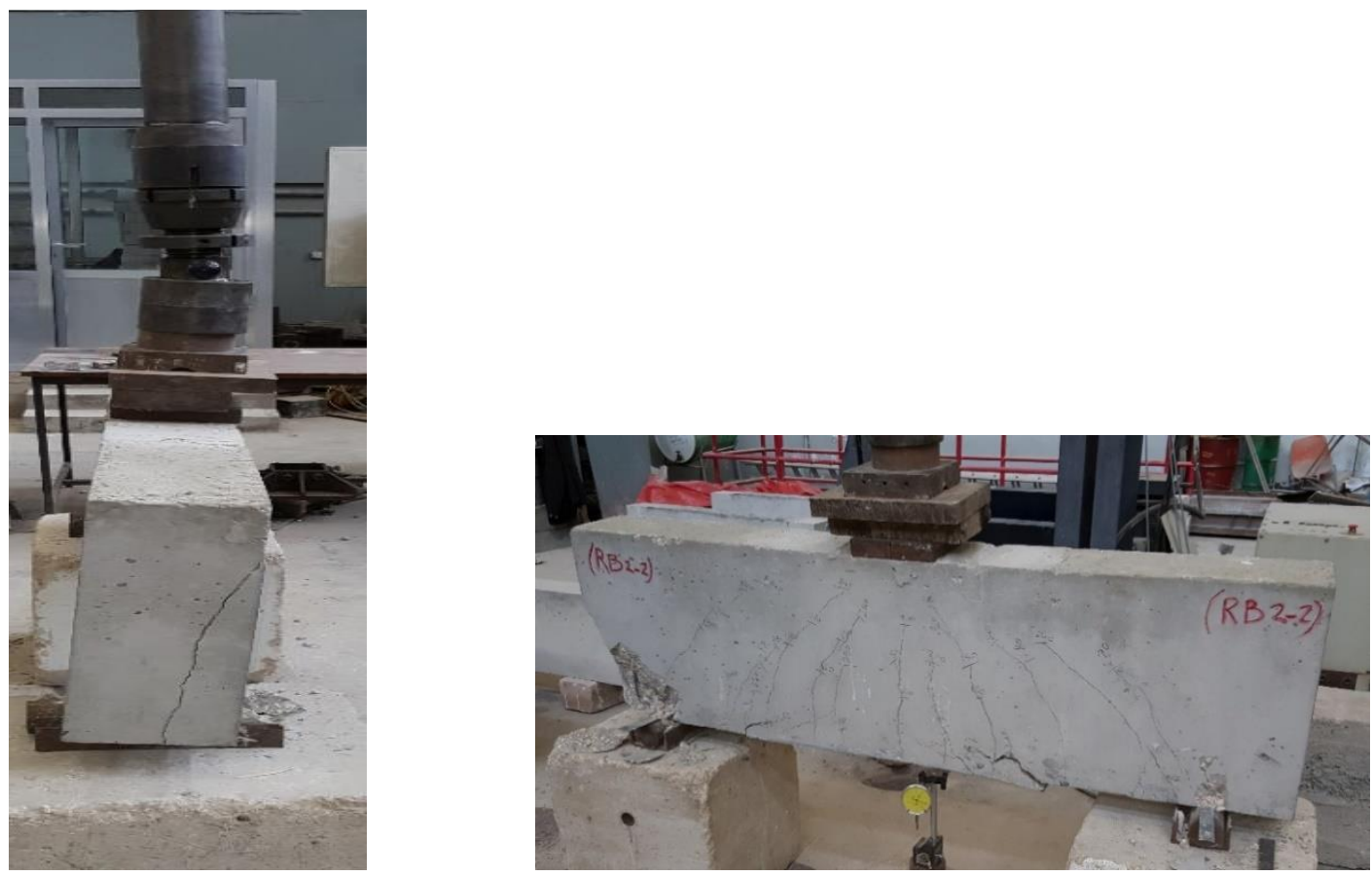

Figure 7. Tilting of Specimens

The rehabilitated beams were tested under one concentrated load and in two phases; phase one (pre-cracked phase) and phase two (rehabilitated phase). Beams in pre-cracked phase were tested until the load was reached an approximate value $300 \mathrm{kN}$ (i.e. $60 \%$ of the average ultimate load capacity of the control beams); and then the beams were removed and rehabilitated with MBrace laminate and MBrace Fiber 230/4900.

\subsubsection{Results of Rehabilitated Beams in Pre-cracked Phase}

\subsubsection{Crack Pattern}

Figure 8 shows the crack patterns (first vertical hairline flexural cracks at mid-span of the beam and diagonal shear cracks in both left and right shear spans as well as diagonal shear cracks at one or both supports in some specimens) of six rehabilitated beams.

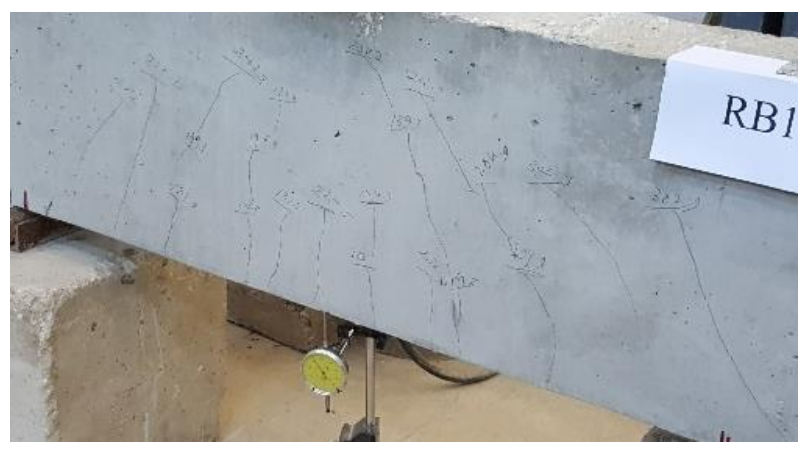

RB1-1 


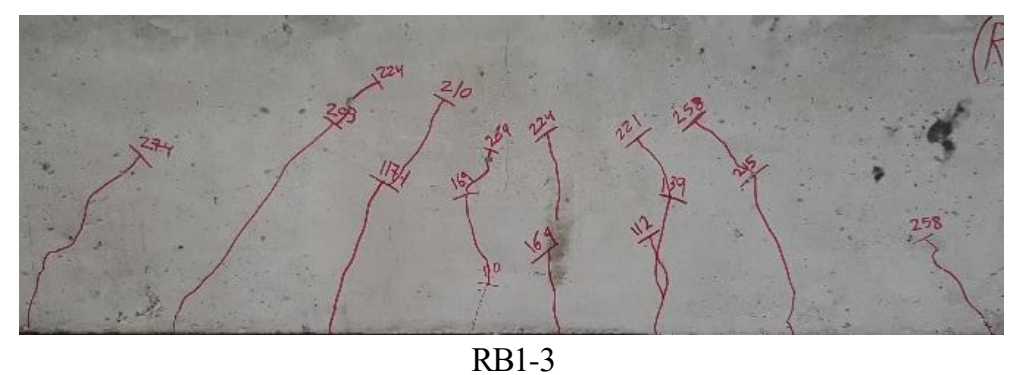

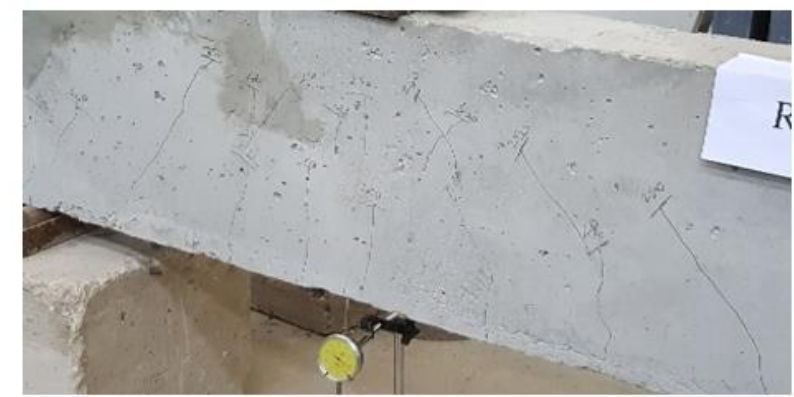

RB2-1

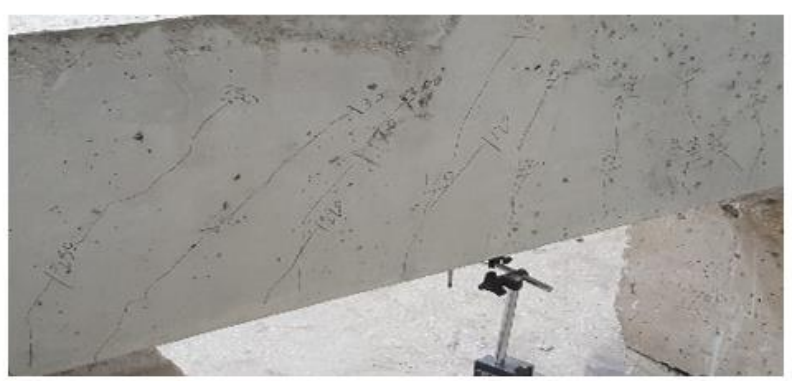

RB3-1

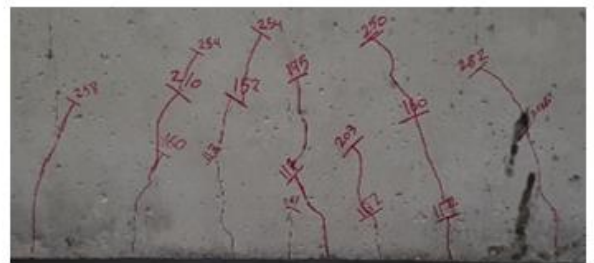

RB2-3

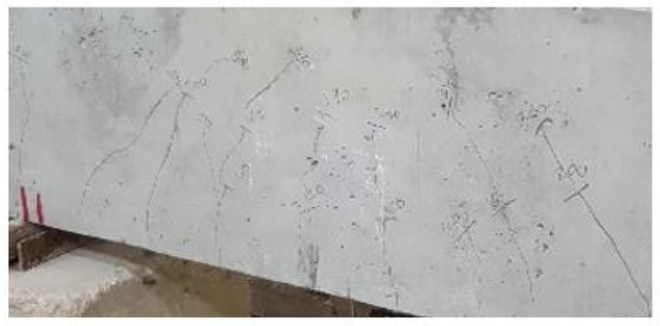

RB3-2

Figure 8. Cracks Pattern of Rehabilitated Beams in Pre-Cracked Phase

\subsubsection{Load versus Vertical Mid-Span Deflection}

A comparison in the response of load against vertical mid-span deflection between rehabilitated beams of each test group is presented in Figure 9.

\section{Load vs Deflection}

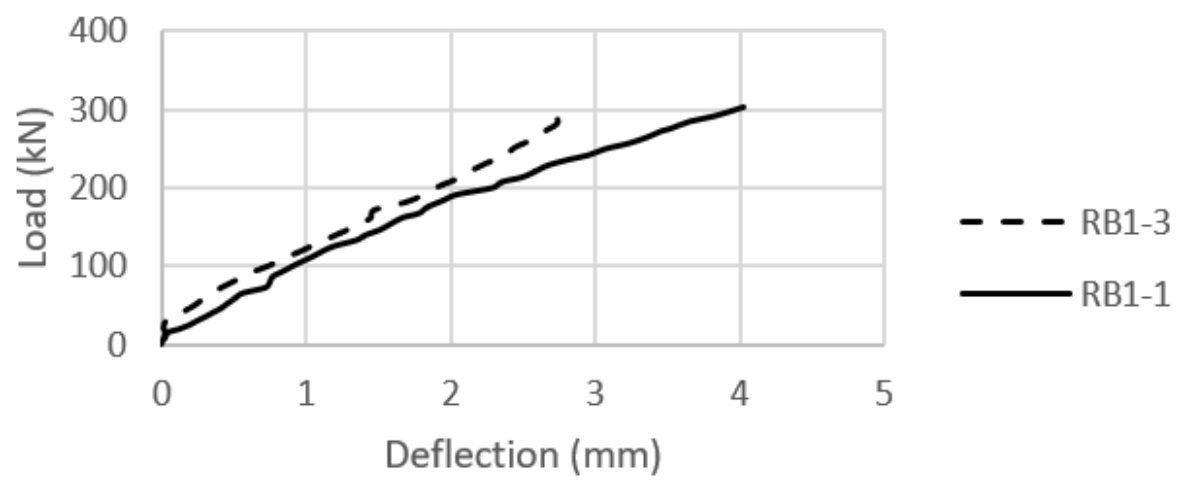




\section{Load vs Deflection}

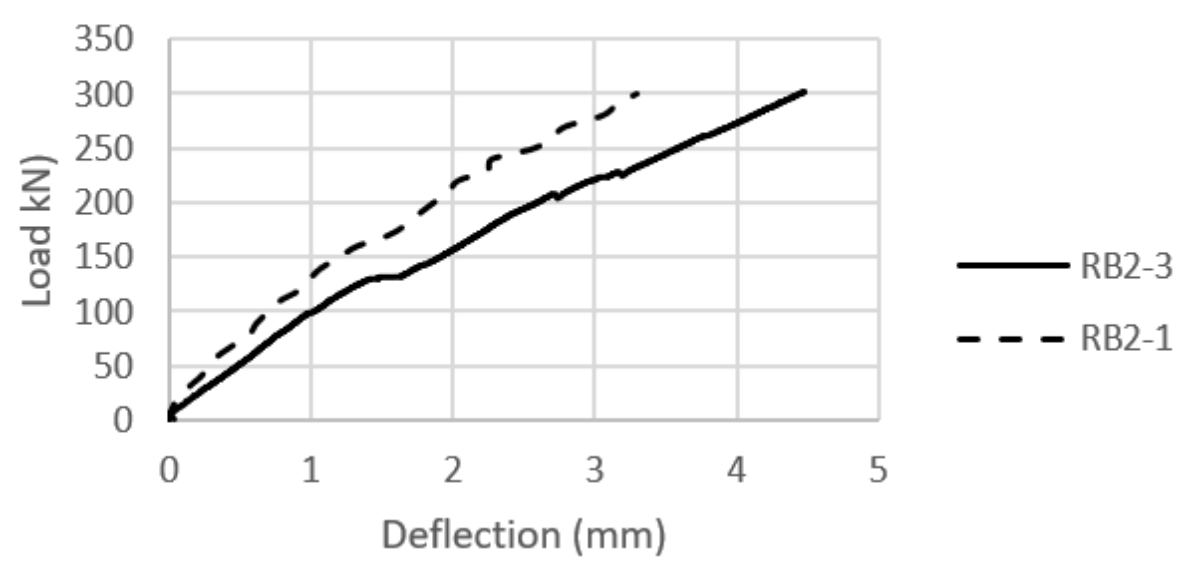

\section{Load vs Deflection}

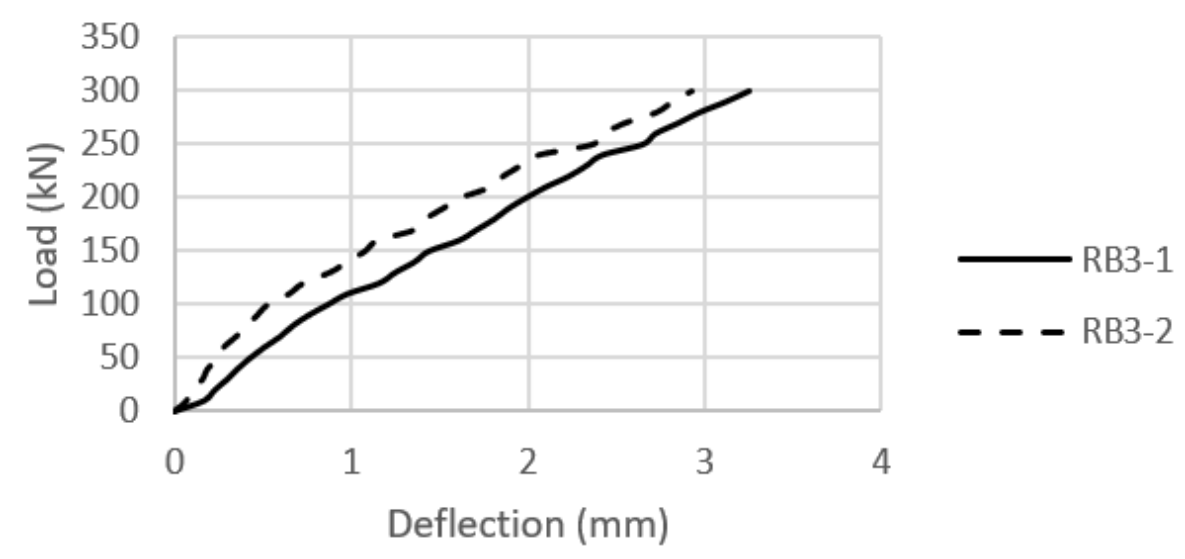

Figure 9. Comparis on of Load versus Vertical Mid-Span Deflection between Rehabilitated Beams for Each Test Group

Referring to Figure 9, the response of load versus vertical mid-span deflection of rehabilitated beams are approximately the same in the pre-cracked phase.

\subsubsection{Results of Rehabilitated Beams in Rehabilitated Phase}

In this phase, testing was continued after repairing the beams with MBrace Laminate and MBrace 230/4900.

\subsubsection{Ultimate Strength}

Table 4 summarizes test results of six rehabilitated beams with respect to the appearance of first vertical hair line flexu ral cracks, diagonal shear cracks in both shear spans and at both supports, increased width of flexural cracks, enhancements in the ultimate load capacity and the failure mode at ultimate load capacity.

According to Tables 3 and 4, there are some differences in the results between the control beam group and rehabilitated beam groups and also between beams of each group, these differences can be attributed to the difference in testing machines with different load rates and to the external attachment of CFRP to rehabilitated beams. All increased percentages of rehabilitation was with respect to the average ultimate load capacity of control beams. It is clear that there was no improvement in the percentage of rehabilitation in the $3^{\text {rd }}$ test group; which means that scheme of CFRP used in this series is not effective in this test group in enhancing ultimate load capacity of rehabilitated beam with respect to the average ultimate load capacity of control beams. Another issue regarding the enhancement of ultimate load capacity, it is obvious from the test results that the enhancement of CFRP to the load carrying capacity ranged from $2.9 \%$ to $13.1 \%$ of rehabilitated beams in the $2^{\text {nd }}$ and $4^{\text {th }}$ test group. 
Table 4. Test Results of Six Rehabilitated Beams

\begin{tabular}{|c|c|c|c|c|c|c|c|c|c|c|c|c|}
\hline \multirow{3}{*}{ Comparison Issue } & \multicolumn{12}{|c|}{ Specimen Designation } \\
\hline & & \multicolumn{2}{|l|}{ RB1-3 } & \multicolumn{2}{|l|}{ RB2-1 } & \multicolumn{2}{|l|}{ RB2-3 } & \multicolumn{2}{|l|}{ RB3-1 } & \multicolumn{2}{|l|}{ RB3-2 } \\
\hline & $\begin{array}{l}\text { Load } \\
(\mathrm{kN}) \\
\end{array}$ & $\begin{array}{l}\% \text { of } \\
\mathrm{UL}\end{array}$ & $\begin{array}{l}\text { Load } \\
(\mathrm{kN})\end{array}$ & $\begin{array}{ll}\% & \text { of } \\
\mathrm{UL} & \\
\end{array}$ & $\begin{array}{l}\text { Load } \\
(\mathrm{kN})\end{array}$ & $\begin{array}{l}\% \text { of } \\
\mathrm{UL}\end{array}$ & $\begin{array}{l}\text { Load } \\
(\mathrm{kN})\end{array}$ & $\begin{array}{l}\% \text { of } \\
\mathrm{UL}\end{array}$ & $\begin{array}{l}\text { Load } \\
(\mathrm{kN})\end{array}$ & $\begin{array}{l}\% \text { of } \\
\mathrm{UL}\end{array}$ & $\begin{array}{l}\text { Load } \\
(\mathrm{kN})\end{array}$ & $\begin{array}{l}\% \text { of } \\
\mathrm{UL}\end{array}$ \\
\hline $\begin{array}{l}\text { First } \text { Vertical Hair } \\
\text { Line } \quad \text { Flexural } \\
\text { Crack }\end{array}$ & 103.7 & 18.5 & 93 & 17.6 & 120 & 23.3 & 113 & 21.4 & 120 & 20.7 & 120 & 21.9 \\
\hline $\begin{array}{ll}\text { Diagonal Shear } \\
\text { Crack in Right } \\
\text { Shear Span }\end{array}$ & 199 & 35.5 & 234 & 44.4 & 180 & 35 & 230 & 43.6 & 220 & 38 & 200 & 36.6 \\
\hline $\begin{array}{l}\text { Diagonal Shear } \\
\text { Crack in Left Shear } \\
\text { Span }\end{array}$ & 213.2 & 38 & 192.4 & 36.5 & 180 & 35 & 230 & 43.6 & 250 & 43.2 & 200 & 36.6 \\
\hline $\begin{array}{l}\text { Diagonal Shear } \\
\text { Crack at Right } \\
\text { Support } \\
\text { (After/before) Reh. }\end{array}$ & $\begin{array}{l}302.9 \\
\text { Bef. }\end{array}$ & $\begin{array}{l}54 \\
\text { Bef. }\end{array}$ & $\begin{array}{l}258 \\
\text { Bef. }\end{array}$ & $\begin{array}{l}48.9 \\
\text { Bef. }\end{array}$ & $\begin{array}{l}250 \\
\text { Bef. }\end{array}$ & $\begin{array}{l}48.6 \\
\text { Bef. }\end{array}$ & $\begin{array}{l}196 \\
\text { Aft. }\end{array}$ & $\begin{array}{l}37.1 \\
\text { Aft. }\end{array}$ & $\begin{array}{l}250 \\
\text { Bef. }\end{array}$ & $\begin{array}{l}43.2 \\
\text { Bef. }\end{array}$ & $\begin{array}{l}300 \\
\text { Bef. }\end{array}$ & $\begin{array}{l}54.8 \\
\text { Bef. }\end{array}$ \\
\hline $\begin{array}{l}\text { Diagonal Shear } \\
\text { Crack at Left } \\
\text { Support } \\
\text { (After/before) Reh. }\end{array}$ & $\begin{array}{l}390 \\
\text { Aft. }\end{array}$ & $\begin{array}{l}69.5 \\
\text { Aft. }\end{array}$ & $\begin{array}{l}274 \\
\text { Bef. }\end{array}$ & $\begin{array}{l}52 \\
\text { Bef. }\end{array}$ & $\begin{array}{l}280 \\
\text { Bef. }\end{array}$ & $\begin{array}{l}54.4 \\
\text { Bef. }\end{array}$ & $\begin{array}{l}246 \\
\text { Aft. }\end{array}$ & $\begin{array}{l}46.6 \\
\text { Aft. }\end{array}$ & $\begin{array}{l}250 \\
\text { Bef. }\end{array}$ & $\begin{array}{l}43.2 \\
\text { Bef. }\end{array}$ & $\begin{array}{l}300 \\
\text { Bef. }\end{array}$ & $\begin{array}{l}54.8 \\
\text { Bef. }\end{array}$ \\
\hline $\begin{array}{l}\text { Widen Width of } \\
\text { Flexural Cracks }\end{array}$ & 500 & 89.1 & 485 & 92 & 400 & 77.7 & 433 & 82 & ------- & ---- & ------- & ----- \\
\hline $\begin{array}{l}\text { Ultimate Load } \\
\text { Capacity }\end{array}$ & 561.3 & ---- & 527.1 & ---- & 541.6 & ----- & 528.1 & ----- & 579.1 & ---- & 547 & ---- \\
\hline$\%$ of Reh. & 9.6 & & 2.9 & & 0.47 & & 3.1 & & 13.1 & & 6.8 & \\
\hline $\begin{array}{l}\text { Failure Mode at } \\
\text { UL. Capacity }\end{array}$ & $\begin{array}{l}\text { Pure } \\
\text { failure } \\
\text { debondin } \\
\text { CFRP }\end{array}$ & $\begin{array}{r}\text { flexural } \\
\text { with } \\
\text { of }\end{array}$ & $\begin{array}{l}\text { Pure } \\
\text { failure } \\
\text { peeling } \\
\text { concrete } \\
\text { supports }\end{array}$ & $\begin{array}{r}\text { flexural } \\
\text { with } \\
\text { off } \\
\text { om both }\end{array}$ & $\begin{array}{l}\text { Pure fle } \\
\text { concrete } \\
\text { CFRP }\end{array}$ & from both & $\begin{array}{l}\text { e with pe } \\
\text { ends of }\end{array}$ & $\begin{array}{l}\text { ling off } \\
\text { aminate }\end{array}$ & $\begin{array}{l}\text { Pure fle } \\
\text { and par } \\
\text { CFRP }\end{array}$ & ial delan & $\begin{array}{l}\text { ure with } \\
\text { ination } 0\end{array}$ & $\begin{array}{l}\text { rupture } \\
\text { f sheet }\end{array}$ \\
\hline
\end{tabular}

\subsubsection{Load versus Vertical Mid-Span Deflection}

This section will introduce a comparison in the response of load-deflection curve between control beams and rehabilitated beams of each group.

\section{Load vs Deflection}

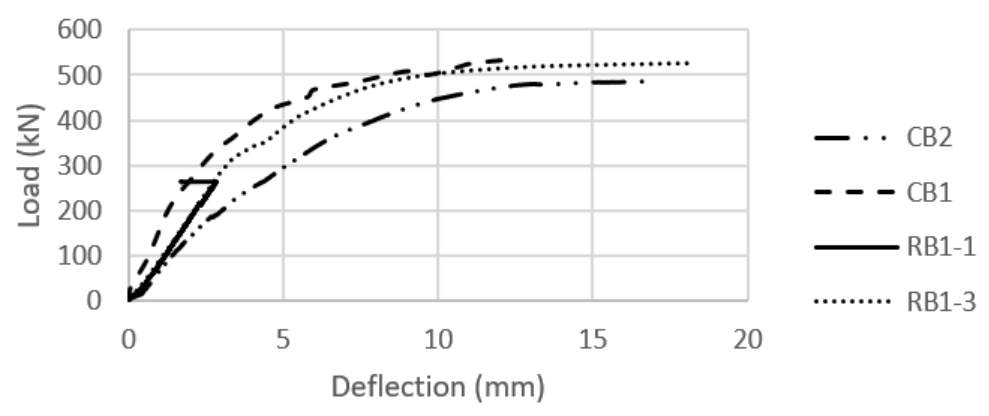




\section{Load vs Deflection}

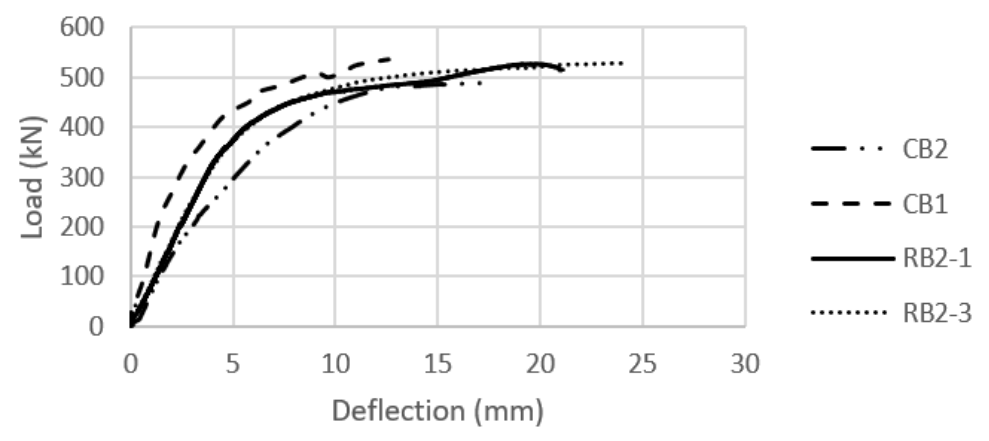

Load vs Deflection

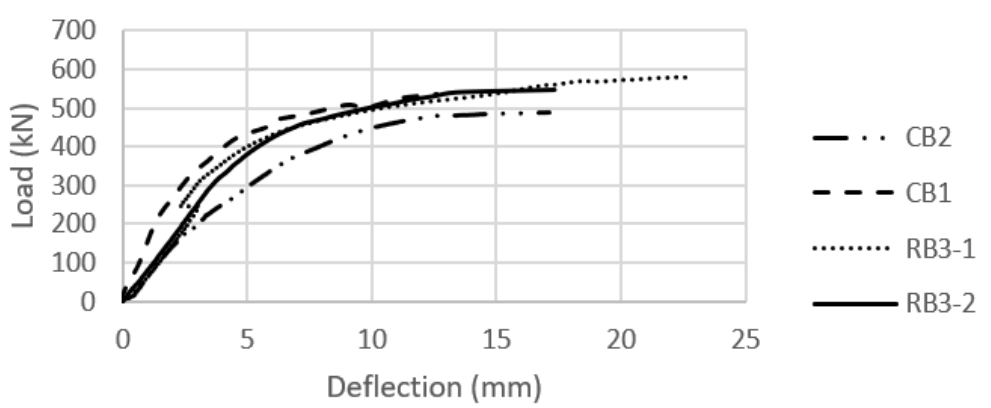

Figure 10. Comparis on of Load versus Vertical Mid-Span Deflection between the Control Beam Group and the Rehabilitated Beam Groups

Referring to Figure 10 and regarding RB1-1, the deflection values were taken until the load reached $265.5 \mathrm{kN}$ because after this reading debonding of CFRP occurred from the middle of the beam and the testing was continued by taking load values only. It is obvious that there was improvement in the response of loaddeflection curve of the $2^{\text {nd }}$ and $4^{\text {th }}$ test groups in comparis on to the average response of the control beams and this was due to the external attachment of CFRP to the rehabilitated specimens.

According to Figure 10, the response of the load-deflection curve of the $3^{\text {rd }}$ test group was approximately the same as the average response of the control beams, which indicates that scheme of CFRP used in this case has no significant effect in the $3^{\text {rd }}$ test group.

\subsubsection{Failure Modes}

In this section the failure mode of each rehabilitated beam is presented. The first beam of the $2^{\text {nd }}$ test group failed in pure flexure with debonding of laminate CFRP whilst the second beam failed in pure flexure with an additional peeling of the concrete from both supports. Beams of the $3^{\text {rd }}$ test group failed in pure flexure with peeling of the concrete from both ends of the laminate CFRP. Regarding the $4^{\text {th }}$ test group, both beams failed in pure flexure with rupture and partial delamination of CFRP sheet. When failure of RB3-1 and RB3-2 was reached at ultimate load capacity; the CFRP s heet was removed to see exact failure mode of these beams. Figure 11 shows the failure modes of the rehabilitated test groups. 


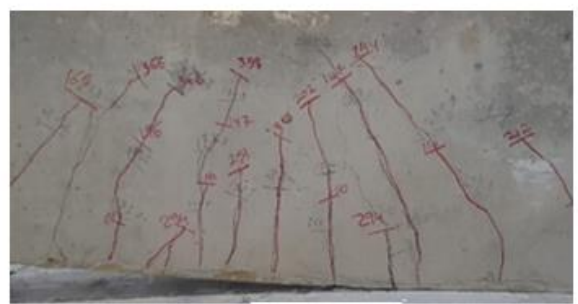

RB1-1

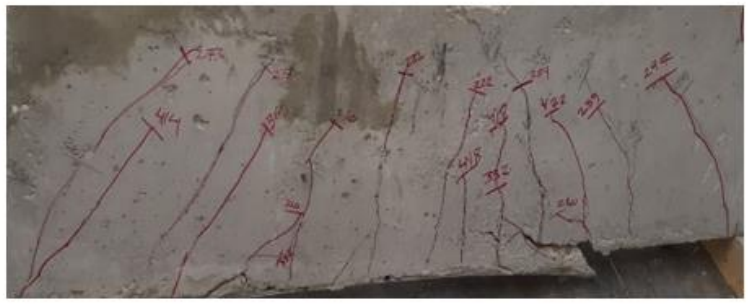

RB2-1
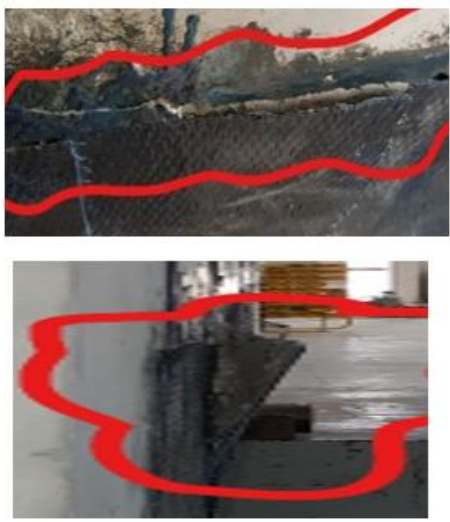

Partial Delamination of CFRP Sheet

Rupture of

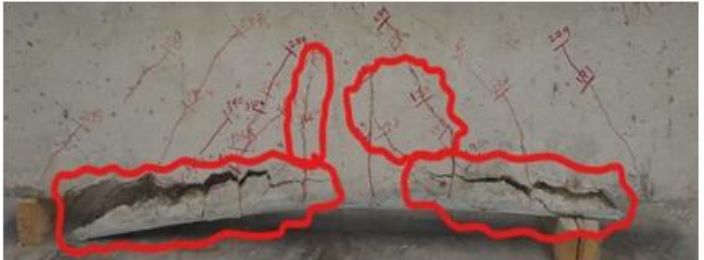

RB1-3

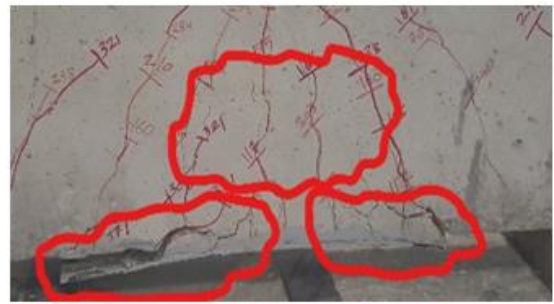

RB2-3

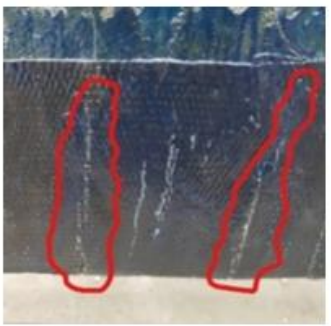
CFRP Sheet

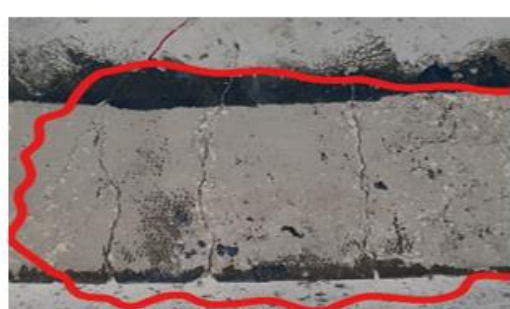

RB3-1

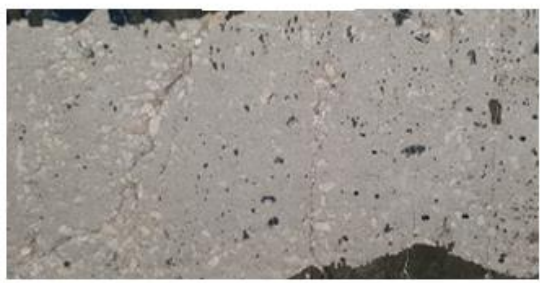

RB3-2

Figure 11. Failure Modes of Rehabilitated Test Groups

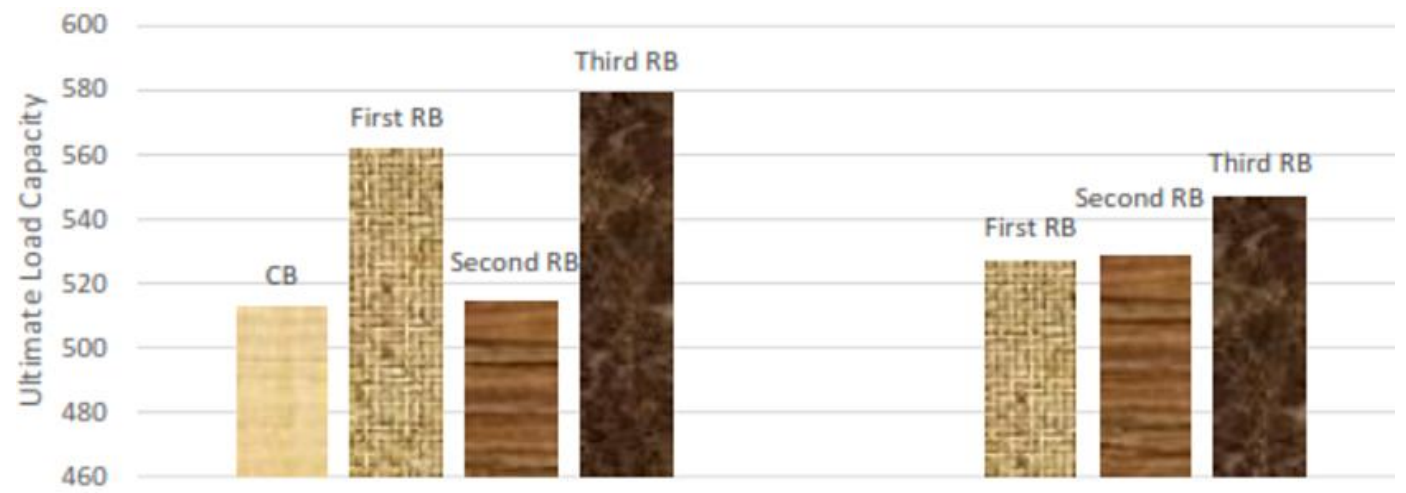

풀 Average Ultimate Capacity of Control Beam Group 빼 First Rehabilitated Beam Group

ESecond Rehabilitated Beam Group

- Third Rehabilitated Beam Group

Figure 12. Results Summary Illustration 


\subsection{Summery}

Figure 12 illustrates the enhancement in ultimate load capacity of each rehabilitated beam with respect to the average ultimate load capacity of control beams.

Referring to Figure 12, it is obvious that the results of rehabilitation in the $2^{\text {nd }}$ and $4^{\text {th }}$ test groups are close to each other, but with taking into the account the high cost of CFRP material, scheme of CFRP material in the $4^{\text {th }}$ test group is more effective over the $2^{\text {nd }}$ test group.

\section{Conclusions}

According to the experimental results of retrofit deep beams by using CFRP, the following conclusions were arrived at:

1. Externally bonded CFRP to pre-cracked beams delays the occurrence of diagonal shear cracks at both span ends as well as enabling an increased width of the vertical flexural cracks of rehabilitated beams to be acceptable compared to the control beams.

2. Both CFRP laminates and sheet retrofitted deep beams showed a significant increase in the ultimate load carrying capacity in reference to the control beam. The enhancement magnitude of retro fitted de ep beam ranged from $2.9 \%$ to $13.1 \%$.

3. Tests showed that the $2^{\text {nd }}$ group using CRFP laminates showed a remarkable load carrying capacity increase when compared to the $3^{\text {rd }}$ test group.

4. When varying the length of laminate and keeping all other variables unchanged (i.e., the $2^{\text {nd }}$ and $3^{\text {rd }}$ groups), the use of full length between supports proved to be more effective in increasing the load carrying capacity when compared to the use of partial length laminates.

5. External bonding of CFRP to pre-cracked beams enhances the load carrying capacity when compared to control beams. Enhancement of load carrying capacity in the $2^{\text {nd }}$ test group (i.e., the laminate group) was 9.6\% for RB1- 1 and $2.9 \%$ for RB1-3, while for the $4^{\text {th }}$ test group (i.e., the sheet wrapped group) was $13.1 \%$ for RB3-1 and $6.8 \%$ for RB3-2.

6. According to the results of this study, the more effective scheme of CFRP in enhancing flexural performance of simply supported RCDBs is CFRP wrapped sheets (i.e. the $4^{\text {th }}$ test group).

\section{Recommendations and Future Works}

- Regarding test results of this study, more researches and studies are required for rehabilitation of RCDBs with more schemes of CFRP laminates and sheets in order to improve flexural performance of RCDB in old, new, and existing buildings and bridges.

- More schemes of CFRP composites are required for rehabilitation of RCDBs to improve flexural performance. External attachment of CFRP is required not only from the tension face of the beam, but also from both sides of the beam in order to improve flexural performance and to avoid debonding of CFRP composites.

- Finite element analysis is recommended for rehabilitation of RCDBs with CFRP composites by using ANSYS or ABAQUS software.

\section{Acknowledgments}

The authors would like to acknowledge the financial support by the deanship of academic research and the technical support by the department of civil engineering at the University of Jordan.

\section{References}

ACI Committee 318 (2014). Building Code Requirements for Structural Concrete (ACI 318M-14) and Commentary (318RM-14). American Concrete Institute, Michigan: Farmington Hills.

ACI Committee 440 (2008). Guide for the Design and Construction of Externally Bonded FRP Systems for Strengthening Concrete Structures (ACI 440.2R-08). American Concrete Institute, Michigan: Farmington Hills.

Ahmad, S., Elahi, A., Barbhuiya, S. A., \& Farid, Y. (2012). Use of poly mer modified mortar in controlling cracks in reinforced concrete beams. Construction and Building Materials, 27(1), 91-96. https://doi.org/10.1016/j.conbuildmat.2011.08.023

Ahmadi, M. (2013). Analysis of Rehabilitation Effect on the Improvement Capacity of Reinforced Concrete Beams with FEM. Procedia Engineering, 54,327-340. https://doi.org/10.1016/j.proeng.2013.03.030 
Ali, N., Abdul, S., Abdul, A., Mohamada, N., \& Jayaprakash, J. (2013). Shear Behaviour of Pre-cracked Continuous Beam Repaired using Externally Bonded CFRP Strips. Procedia Engineering, 53, 129-144. https://doi.org/10.1016/j.proeng.2013.02.019.

Al-Sarraf, S. Z., A1-Shaarbaf, I. A. S., \& Diab, A. S. (2011). Effect of Steel Fiber on The Behavior of Deep Beams with and Without Web Opening. Eng. \& Tech. Journal, 29(1), 1-17.

ASTM C293 (2002). Standard Test Method for Flexural Strength of Concrete (Using Simple Beam with Centre-Point Loading). American Society for Testing and Materials, USA.

Attarde, P. M., \& Barbat, D. K. (2015). Behavior and Strength of Rc Deep Beams Using High Performance Concrete- A Literature Review. International Journal of Modern Trends in Engineering and Research (IJMTER), 2(2), 147-150.

Attarde, P. M., \& Parbat, D. K. (2016). Shear strength and behavior of RC deep beams. International Journal of Research in Engineering, Science and Technology(IJRESTs), 1 (9), 44-49.

Benjeddou, O., Ouezdou, M. B., \& Bedday, A. (2007). Damaged RC beams repaired by bonding of CFRP laminates. Construction and Building Materials, 21(6), 1301-1310. https://doi.org/10.1016/j.conbuildmat.2006.01.008

Burningham, C. A., Pantelides, C. P., \& Reaveley, L. D. (2015). Repair of reinforced concrete deep beams using $\begin{array}{lllll}\text { post-tensioned CFRP } & \text { rods. }\end{array}$ https://doi.org/10.1016/j.compstruct.2015.01.054

David, E., Djelal, C., \& Buyle-Bodin, F. (1998). Repair and strengthening of reinforced concrete beams using composite materials. 2nd international $\mathrm{PhD}$ symposium in civil engineering, Budapest.

Kim, S. W., \& Yun, H. D. (2011). Crack-damage mitigation and flexu ral behavior of flexure-dominant reinforced concrete beams repaired with strain-hardening cement-based composite. Composite: Part B, 42(4), $645-656$. https://doi.org/10.1016/j.compositesb.2011.02.022.

Kong, F. K. (2006). Reinforced Concrete Deep Beams, CRC Press.

Nawy. E. G. (2009). Reinforced Concrete: A Fundamental Approach. ACI 318-08 Code (6th Ed.). Upper Saddle River, NJ: Prentice Hall.

Obaidat, Y. T., Heyden, S., Dahlblom, O., Abu-Farsakh, G., \& Abdel-Jawad, Y. (2011), Retrofitting of reinfo rced concrete beams using composite laminates. Construction and Building Materials, 25(2), 591-597. https://doi.org/10.1016/j.conbuildmat.2010.06.082

Suresh, G. S., \& Kulkarn, S. (2016). Experimental study on behaviour of RC deep beams. International Research Journal of Engineering and Technology (IRJET), 3(8), 676-679.

\section{Copyrights}

Copyright for this article is retained by the author(s), with first publication rights granted to the journal.

This is an open-access article distributed under the terms and conditions of the Creative Commons Attribution license (http://creativecommons .org/licenses/by/4.0/). 